\title{
METHODOLOGY OF TEACHING HISTORY AND HISTORY BOOKS IN THE ESTONIAN SSR
}

\begin{abstract}
Kari KAUNISMAA
University of Turku, Department of Political History, Finland; kari.kaunismaa@paimio.fi

A survey is given of the methodology of teaching history and of the textbooks used. In the centralised system of the Soviet Union history had to be taught in the same way in the whole country. Until Stalin's death in 1953 all history textbooks used in Estonia were translated from Russian. Important aims were to wipe out the time of Estonian independence in 1918-1940 from the memories of Estonians and to shake national identity. Falsification of history and worship of MarxismLeninism and socialism were used to achieve these aims.
\end{abstract}

\section{BACKGROUND}

Studying the methodology of teaching history in the Soviet Union first came of interest after the collapse of the whole system and the Marxist-Leninist explanation of history. I have mostly studied the methodology and books used in the Russian Federation both in the Soviet and the post-Soviet era. Like the Finnish scholar Sirkka Ahonen has pointed out, school history in a centralised system tends to be a society's official representation of itself. Simple interpretations and myths are served for the people to identify with. Ahonen studied both East Germany and Estonia during the Great Change in 1986-1991, found some liberal tradition in the past of both countries, but also an authoritarian tradition much heavier in East Germany than in Estonia. ${ }^{1}$ While Ahonen concentrated on school curricula and interviews, I have studied methodological instructions and school history textbooks. The Estonian SSR is a special case for me in studying the Soviet Union because of the relation of Finnish and Estonian languages and geographical neighbourhood.

Ahonen describes the struggle for National History Education in the Baltic countries. From the all-Soviet conference of education held in Riga in 1986 onwards it was clear that Moscow was not ready to accept the Baltic tempo. Ahonen tells about H. Piirimäe, who wrote about Soviet chauvinism in 1990. It deprived children

\footnotetext{
1 Ahonen, S. Clio sans uniform. A Study of the Post-Marxist Transformation of the History Curricula in East Germany and Estonia. Helsinki, Suomalainen tiedeakatemia, 1992, 16.
} 
of a notion of their homeland, implied glorification of the proletariat at the cost of educated people, praise of poverty and repudiation of private property, worship of revolutionary violence and denouncement of the religious pursuits of mankind. According to Ahonen the Estonian history curriculum of 1990 was not an old style politically sanctioned directive, but a product of an open process of educational planning, subject to free criticism of those concerned. This was the big difference to the old system. ${ }^{2}$

Another Finnish scholar, Pertti Grönholm, has shown that the main thing in the Soviet-type historiography was to wipe out the time of Estonian independence in 1918-1940 from the memories of Estonians. He tells in his doctoral thesis "The History of a National Failure" that at least the history writing should shake the faith of Estonians to the National history tradition and dim the sense of history. Grönholm has divided the model formal and informal functions of Soviet historiography by Nancy Heer into three groups: (1) propagandist-pedagogical, (2) political-pragmatic and (3) ideological-theoretical functions. Grönholm also has studied the common Estonian history books like Eesti NSV ajalugu I-III (History of the Estonian SSR I-III) and some books for universities like Eesti NSV ajalugu. Kõrgkoolide oppik (History of the Estonian SSR. Textbook of higher schools), $1976 .{ }^{3}$

I have here concentrated on the pedagogical part and school history books.

According to Grönholm, the Estonian identity, anchored to national history and culture surprisingly proved to be more powerful than the Soviet system with its propaganda and violence machinery. He says that the Soviet historiography partly actually confirmed (through the negation) the attachment of Estonians to their national history tradition. From this point of view it is possible to see the whole Marxist-Leninist narrative about the Estonian history as dysfunctional for the Soviet power. The culmination point was the human chain through the Baltic States in August 1989. ${ }^{4}$ A Swedish scholar Karlsson states that the power of the Baltic liberation process was a common concept of history and a consciousness of its crucial importance for the present moment.

Without interviews it is naturally impossible to find evidence about what actually happened in the classroom. Dr. Magnus Ilmjärv has told me in several seminars in Finland that in spite of the book contents an Estonian history teacher could tell the national version of history to the pupils - and very often did so. Of course the national point of view was maintained in families as an oral tradition without any written documents. I now have pointed the focus on written sources about methodology and textbooks of history.

2 Ahonen, S. Clio sans uniform, 105, 128.

${ }^{3}$ Grönholm, P. Kansallisen epäonnistumisen historia. Neuvostovirolaisen historiankirjoituksen kertomus ja tulkinnat Viron tasavallan ajasta. Yleinen historia. Turun yliopisto, 2001.7.21 (CD-ROM). (Orig. Heer, N. Politics and History in the Soviet Union. Cambridge, MIT Press, 1971.)

4 Grönholm, P. Kansallisen epäonnistumisen historia, 489-490.

${ }^{5}$ Karlsson, K.-G. Historia som vapen. Falun, AiT ScandBook, 1999, 232. 


\section{QUESTIONS}

In a totalitarian state the same subjects were taught on the same day to pupils from Kaliningrad to Vladivostok, especially in history. According to Ahonen the children who had studied the Stalinist history in school, with all its blank spots and distorted facts, were considered a lost generation. ${ }^{6}$

I tried to find out:

- Were there any nationalist concepts or characteristics in Estonian history books?

- If yes, did the number of them increase from the 1940s to the 1980s?

- Were there any positive achievements in the Communist era from a Western Liberal point of view?

According to Ahonen the Marxist history is based on the changing of social formations rather than on the mere passing of events. Revolutions are the driving force of history and progress is the covering law. ${ }^{7}$ I formulated the question whether it is possible to find any exceptions from a deductive Marxist-Leninist method in the Soviet Estonian historiography. I also tried to find comparisons between Soviet and Western schools and methods.

\section{SOVIETISATION OF TEACHING HISTORY AFTER WORLD WAR II}

Estonia suffered from three occupations during the war: (1) the annexation to the Soviet Union in June 1940, (2) the German occupation in the summer 1941 and (3) the invasion of the Red Army again in 1944. It was natural that the first instructions in teaching history were derect translations from the Russian language, and the world view was seen through Russian glasses. For example: Although a book is titled Abiks marksistliku filosoofia oppijaile (To help the students of Marxist philosophy), it does not tell a word about the Baltic States. Instead there are numerous mentions about the Soviet Union, Russia and the Red Army when describing World War II. All the writers are Russians. Even more connected to the Kremlin from the same editor is the book Ajaloo oppimisest (About learning history). All the articles are written by Stalin alone or together with Zhdanov and Kirov and they had been published either in the Pravda or in the Bolshevik before. The order of teaching history by the Soviet of People's Commissariat from 16.5.1934 was taken to use in Estonia as such. ${ }^{8}$

In the same way the book NSV Liidu ajaloo metoodika algkooliõpetajaile only tells about Russian history although it is written in Estonian. However, the original volume is written by V. G. Kartsov in Russian, and only the translators and editors are Estonians. The idea is given in a nutshell as follows:

\footnotetext{
${ }^{6}$ Ahonen, S. Clio sans uniform, 126.

7 Ibid., 30.

8 Teder, F. (ed.). Abiks marksistliku filosoofia õppijaile. Tallinn, Poliitiline Kirjandus, 1946, passim; Teder, F. (ed.). Ajaloo õppimisest. Tallinn, Poliitiline Kirjandus, 1949, passim.
} 
Marx ja Engels avastasid esimestena ajaloo seadused, Lenin ja Stalin formuleerisid need ühiskonna arenemise uuele ajajärgule vastavalt. Nende avastamiste tõttu kerkis ajalugu tõelise teaduse kõrgusele. Marksistlik-leninlik ajalugu andis töötajaile kätte hiiglasuure relva: bolševistliku ettenägelikkuse jõu. ${ }^{9}$

[Marx and Engels were the first ones to open the laws of history. Lenin and Stalin formulated them corresponding to the new era of the development of society. Due to this discovery history reached the real level of science. The Marxist-Leninist history gave a giant weapon to workers: The power of the Bolshevik foresight. (My translation.)]

The history from the ancient Kievan Rus becomes very clear to pupils, as well as Ivan the Terrible, Lomonosov and Lermontov, but not at all the Estonian history. The first special book Eesti NSV ajalugu (ed. G. Naan) was published in $1952{ }^{10}$ On the basis of my experience as a teacher I assume that teachers anyway started with domestic Estonian history.

According to Grönholm the spirit of a class struggle was heavily imprinted on school curricula and through the organisations of Komsomol and Young Pioneers. Children of wealthy families were disqualified and those from poorer families favoured. Still most of the teachers were educated in the time of independence and the learning material was printed then. So in practice teaching and learning went on in the old way. The government began to import teachers from other parts of the Soviet Union and to re-educate the Estonian teachers in 1946-1948. Then the Soviet-style teaching replaced the old system. ${ }^{11}$ Still in 1972 Palamets complained about the books conserving the bourgeois ideas. He takes "the legend of the Good Swedish Era" for an example, which should have been rooted out. However, from a pedagogical point of view he is right when saying that the new curriculum of history was badly planned. It consisted of so many unorganised facts that it really was a burden for a common pupil. ${ }^{12}$

The arrogance of the winner of the war was so great that even Estonian editors could not (must not) change anything of the vocabulary. When giving instructions to teachers in the additional education an Estonian Rägastik published the interpretation by a Russian Yakovlev. According to him, the October Revolution had a great importance for the destiny of Slavic peoples, who fought a holy war against German seizers and won supported by the Soviet Army. The European peoples saw for the first time from eye to eye a Soviet man, a Warrior, recognised his high moral values and became fulfilled of wonder and love to him. ${ }^{13}$

The Marxist-Leninist philosophy of course reached the first forms of primary school. According to Melnikov, the aim of teaching history in the primary education

9 Kartsov, V. G. NSV Liidu ajaloo metoodika algkooliõpetajaile. Eds. V. Orav, E. Nurm \& A. Odrats. Tallinn, Pedagoogiline Kirjandus, 1947, 4.

10 Minz (Minz, I. I. Istoriografiya istorii SSSR, Epokha Sotsializma. Moskva, Vyishaya shkola, 1982, 142) claims that Istoriya Éstonskoj SSR was the first one in 1958.

11 Grönholm, P. Kansallisen epäonnistumisen historia, 67.

12 Palamets, H. Eesti NSV ajaloo küsimusi. - Tartu Riikliku Ülikooli Toimetised, 1972, 290, 9.

13 Rägastik, R. (ed.). Abiks õpetajale, kog. nr 1. Tallinn, ENSV Vabariiklik Õpetajate Täiendusinstituut, Pedagoogiline Kirjandus, 1948, 47-51 (orig. Yakovlev in Bolshevik No 22, 1947). 
was to create an understanding in pupils that everything changes, everything moves ahead and the old one changes to the new. Even a more specific target was to educate an undistinguishing love to Fatherland and people, a warm patriotism and a national pride as citizens of the First Socialist Country in the world, and hatred to all enemies and persecutors of workers. Here also appears the concept of Russia as saviour of Western Europe from the Mongols by the blood of its own people. ${ }^{14}$ In these circumstances there was no room for Estonian national history to come into daylight in textbooks. The Estonian author Jaan Kross describes this point of view of a Great nation in his historical novel Kolme katku vahel when writing about Balthasar Russow studying in Stettin in the 16th century. The German principal Wolff of the university cannot understand that an Estonian does not speak a Slavic language. The principal himself has regarded all the peoples living in the east from Germans as Slavic. ${ }^{15}$ In the same way Õispuu carefully presents the scheme of Slavic peoples but does not tell a word about the relationship between Estonians, Hungarians and Finns. ${ }^{16}$ The Soviet history writing did not pay any attention to the role of small nations either.

All the "wrong" books from the schools were collected into a closed fund in the University of Tartu in 1950. For example the literature dealing with "questions of the working class in a wrong way" was censored. Even the books by Russians Pokrovsky and Klyushchevsky were drawn out. As clear as possible was the statement by Nikolai Karotamm, the 1st secretary of the Estonian Communist Party (ECP), who said that the ECP had never regarded Estonia as an independent country in any form. The periods of the era 1920-1940 were renamed as "The provisional consolidation of the bourgeois power" (1925-1929), "The deepening political crisis of the bourgeois power" (1930-1934) and "The power of the fascist gang of Päts" (1934-1940). ${ }^{17}$

The teachers were under a hard pressure and political control. It was not surprising that the sentence "Karl XII won the battle of Narva" in an Estonian grammar was replaced with the sentence "Peter the Great won the battle of Poltava". Even in mathematics every reference to bourgeois life like real estate, salaries paid by private employers etc. had to be removed. Pupils protested for example by singing "The Internationale" in Estonian and replacing "slavery" with "Stalin": "Rise all persecuted by Stalin." There are several members of the Communist youth organisation among the pupils and students who discriminated the majority. ${ }^{18}$

14 Melnikov, M. A. (ed.). Nachal'naya shkola, Nastol'naya kniga uchitelya. Moskva, Gosudarstvennoe uchebno-pedagogicheskoe izdatel'stvo prosveshcheniya RSFSR, 1950, 50-53.

15 Kross, J. Uppiniskaisuuden kronikka. Juva, WS Bookwell Oy, 2003, 297 (orig. Kolme katku vahel I-IV, 1970-80).

16 Õispuu, S. Metoodiline juhend VII klassi NSV Liidu ajaloo töövihiku kasutamiseks. Tallinn, Eesti NSV Haridusministeerium, 1983, 27.

17 Grönholm, P. Kansallisen epäonnistumisen historia, 87, 94-95.

18 Oras, A. Viron kohtalonvuodet. Jyväskylä, Gummerus, 1958, 126-127, 299 (orig. Baltic Eclipse, 1948). (The publication in Finland was an example of liberation during the Thaw of Khrushchev.) 


\section{HISTORY BOOKS WRITTEN IN EXILE}

Tens of thousands of Estonians moved to Sweden, Germany, the United States and Canada in 1944-1946 because of the Soviet occupation. It was only abroad that the national Estonian way of history writing could be carried on. As early as in 1951 Evald Uustalu wrote a book The History of Estonian People in Stockholm, which then was published in London. Like Marxist-Leninist authors he also sees Estonia and Livonia as a battlefield of Western and Eastern conquerors in the Middle Ages and some centuries after. Czar Peter the Great made Estonia part of the Russian Empire in the Peace Treaty of Uusikaupunki (Nystad) in 1721. Estonia then stayed as a province until the October Revolution in 1917. However, then the difference comes: While Soviet-style textbooks tell very little about the national and political awakening in Estonia in the 19th century, Uustalu describes it for a whole chapter, 70 pages. There are names like Faehlmann, Kreutzwald, Jannsen, Koidula, Hurt and Jakobson. ${ }^{19}$ We can state that without this creation of a national culture it would not have been possible to form an independent state in 1918.

The Russian standardisation efforts (Gleichschaltung) in the Baltic area began already in 1885 while in the Grand Duchy of Finland they first started with the February Manifest in 1899. All the Estonian schools were placed under the Russian Ministry of Education. Russian was made the language of instruction and Estonian was permitted only during the first two school years. The determination of the Russian authorities was to denationalise and Russify the Estonians within the shortest possible period. The sufferers were mostly children: not knowing Russian their first years at school were wasted and the general level of education fell significantly. Even the University of Tartu (Dorpat) was renamed as Russian Yuryev. A significant detail in Uustalu's book is that there is a picture of the very same University of Tartu with a mention: Founded by the Swedish King Gustavus Adolphus in $1632 .{ }^{20}$ In Soviet Estonia the same university was presented without a word of the Swedish era, as if it had been a Russian invention and product. ${ }^{21}$ In exile professor Ants Oras completed the history of the University by saying that it was founded by liberal Swedes, robbed and interrupted by Russians, re-opened by Baltic Germans encouraged by Czar Alexander I. But the Germans limited the University only for their own ruling class and tried to keep Estonians and Latvians outside. $^{22}$

The older schoolmasters were replaced by younger men whose main task was to hammer a foreign language into their pupils. The favourable market conditions

19 Uustalu, E. The History of Estonian People. London, Boreas Publishing, 1952, 122-193.

20 Ibid., 209.

21 Anatoli Lehtonen in Õispuu, S. (ed.). Ideeline kasvatustöö ajaloo õpetamisel. Metoodilised juhendid. Tallinn, Eesti NSV Haridusministeerium, Eesti NSV Pedagoogika Teadusliku Uurimise Instituut, 1978, 45. (The University was re-opened in 1802.)

22 Oras, A. Viron kohtalonvuodet, 90. 
were damaged as were independent farmers. ${ }^{23}$ We can assume that when not mentioning this Russification the Marxist-Leninist historiography only regarded it as natural development, although it was made by the Czarist regime.

Uustalu calls the Declaration of Independence from 24 February 1918 with its own name. In the Soviet context the period of independence was called "Under the yoke of the national bourgeoisie" still in $1986 .{ }^{24}$ Uustalu also pays attention to Finnish voluntary troops who came to Estonia at the end of 1918 just at the right moment to refresh the spirit of Estonian soldiers fighting against the Russian forces. ${ }^{25}$ The peace treaty was signed in Tartu in February 1920.

After several years of peaceful development the League of the Veterans of the Estonian War of Independence (VAPS) attempted to make a coup d'état. The Government proclaimed a state of emergency in March 1934, arrested the leaders of veterans and in fact put an end to all political life for many years. Estonia went to World War II under the autocracy of President Konstantin Päts. ${ }^{26}$ Still, as a symbol of freedom Uustalu gives the passenger lines: In 1937 ships sailed regularly from Tallinn to Helsinki, Stockholm, Stettin and Great Britain. An Estonian airline maintained a service between Tallinn and Helsinki, while several foreign airlines connected the capital with Helsinki, Stockholm, Leningrad, Warsaw and Berlin. ${ }^{27}$

In most of the books of Russian origin there is a mention about literacy: It was after the October Revolution that people first learned to read. Uustalu here gives an exact number about Estonia: As early as in 1886, 98 per cent of Estonians recruited for service in the Imperial Russian Army were able to read and write. ${ }^{28}$ In Russian census from 1897, 79 per cent of all inhabitants of the empire were illiterate. ${ }^{29}$ Finland was excluded because everybody could read thanks to the persistent work of the Evangelical Lutheran church after the Reformation. One can assume that the same reason influenced in Estonia. Oras states that the educational level seems to be higher in Russia than before the war, but in Estonia it was very much lower than in the 1920s and 1930s. Those who had finished a professional school can call themselves "agronomists", "vet technicians" or even "lawyers" although they only spent 10 years in school counting from the very first day in primary school. ${ }^{30}$

In a clear way Uustalu brings the secret clause of the Treaty from 23 August 1939 into the daylight. With signatures of Molotov and Ribbentrop the two totalitarian powers divided the whole area into spheres of interest. Finland, Estonia and Latvia were assigned to the Soviet orbit and Lithuania to Germany. Poland

Ibid., 136-138.

24 Kahk, J. \& Siilivask, K. Eestin SNT:n historia. Tallinn, Perioodika, 1986, 92.

25 Uustalu, E. The History of Estonian People, 169.

26 Ibid., 199-208.

27 Ibid., 219.

28 Ibid., 221.

29 Anweiler, O. \& Ruffmann, K.-H. Kulturpolitik der Sowjetunion. Stuttgart, Alfred Kröner Verlag, 1973, 7.

30 Oras, A. Viron kohtalonvuodet, 298. 
was divided in two. A month later Lithuania was included in the Soviet sphere of interest. Estonia was put at the mercy of the Soviet Union. Russia had the right to maintain naval bases on the whole Estonian coast and a number of air bases. This development led to a complete Russian occupation in June 1940 and to a "voluntary" incorporation into the Soviet Union in July. All the Baltic States were accepted into the Soviet Union in the session of the Supreme Soviet of the USSR in August 1940. ${ }^{31}$

Of course there appeared resistance to the occupation. According to Uustalu the fates of those arrested by NKVD varied. The graves of 1900 persons executed in Estonia have been traced, but some 10000 were deported to the Soviet Union. In addition about 1100 persons vanished without trace during the first Soviet occupation. To Uustalu the fate of Konstantin Päts and General Johannes Laidoner was still unknown. On 13 June 1941 NKVD arrested 10200 Estonians in a single night and deported them to Siberia. Soon after the outbreak of the war with Germany, over 33000 Estonian mobilised men were deported to timber camps in the Russian Far North. The majority died there. Of Estonia's population of 1100000 nearly 60000 perished or vanished during the one year of Soviet occupation in 1940-1941. ${ }^{32}$

The second occupation of Estonia began in summer 1941, this time by the Germans. According to Uustalu the German leaders had never really abandoned their ambitions in the Baltic. Hitler offered to repatriate all Baltic Germans who had made their home there for seven hundred years. After the attack eastwards on 22 June 1941 the whole of Estonia was in the hands of Germans by 21 October. Interesting enough, Uustalu tells about the partisan movement Metsavennad, men who escaped into forests and then supported the German troops in their attacks. In time it however became clear that Germany did not intend to restore Estonian independence. Estonian volunteers were good patriots and refused to join the Estonian Legion, which was founded in 1942 as a Waffen SS unit. In 1944 the East Battalions were compulsorily amalgamated with the Waffen SS formations. ${ }^{33}$ Although the Finnish SS Battalion fought in the Ukraine and Caucasus, Marshal Mannerheim denied a new agreement with Germans already in summer 1943.

According to Uustalu the Finnish Government allowed Estonians to join the Finnish army. "Soome poisid" formed a whole regiment in the army and some 800 men in the navy. About 2000 men returned to Estonia in September 1944 to fight to the last in defence of their homeland. Estonia was ruled by a Generalkommissar. Gebietskommissare were appointed to each county and were answerable to the Governor-General. The Estonian patriots still tried to return their independence and formed the National Committee of the Estonian Republic under the lead of Jüri Uluots in March 1944. The Gestapo soon arrested many of its members. In the economic field the Soviet industrial departments were only renamed Ostland-

31 Uustalu, E. The History of Estonian People, 238-243.

32 Ibid., 244-249.

33 Ibid., 249-252. 
Gesellschaften. When the Russians re-occupied Estonia in 1944, they noticed that Germans had not undone their work either in collectivisation or in any other field. ${ }^{34}$

After the general attack on the Finnish front in June 1944 the Soviet army directed its main weight to bear on Estonia and Latvia. The ceasefire between Finland and the Soviet Union and the provisional peace agreement in September freed vast Russian troops to the Estonian front. All was over by the end of November. According to Uustalu the advance of the Red Army into Estonia was marked by robbery, violence, rape and murder. Between 1941 and 1946 the population of Estonia shrank by 18 per cent or 200000 people. There were no mass deportations in Estonia during the war but they were resumed four years later, in 1949 when Estonian agriculture was collectivised. The capitulation of Nazi Germany and the end of the war brought no message of joy or relief to the Estonian people. Liberation from the Nazi yoke merely meant the closing of the gates of their Soviet concentration camp. ${ }^{35}$

\section{THE MARXIST-LENINIST HISTORIOGRAPHY OF ESTONIA}

When describing the industrialisation of Estonia in the second half of the 19th century the textbooks mostly put the focus on formulating the proletariat. It is true that the length of a working day was 14 hours, wages and salaries were low, factories were noisy and dirty and an employee who lost his ability to work was dismissed at once without any compensation. They also had to buy their groceries from the factory shop at high prices. Two thirds of the peasants had no cultivated land, which mostly belonged to German landlords. Almost all the people had no civil rights and they were ruled by Czarist administrators. On every Sunday pastors preached in churches and told people to obey the landlords. However, then emerged an Estonian national movement, a progressive one in its time, involving peasants, countryside bourgeoisie, workers, intelligentsia and the petite bourgeoisie in towns. ${ }^{36}$

The importance of culture for Estonians appears also in telling about Estonianlanguage schools, Estonian literature, songs, paintings, magazines and theatre plays. The first Estonian Song Festival was held in Tartu in 1869. The singing of patriotic Estonian songs at this festival is remembered with pride. ${ }^{37}$ History repeated itself again in 1989 with the Estonian Singing Revolution, this time against the Soviet power. However, the picture given in the 1960s highlighted the role of the national movement as a new period when great masses began their struggle against czarism, landlords and capitalists. ${ }^{38}$

34 Uustalu, E. The History of Estonian People, 252-253.

35 Ibid., 254-256.

36 Palamets, H. \& Vahtre, S. Iz istorii Éstonskoj SSR. Tallinn, Éstonskoe gosudarstvennoe izdatel'stvo, 1962, 32-37.

37 Ibid., 38-39.

38 Ibid., 42. 
At the beginning of the 20th century Estonia was the most important industrialised area in the Czarist Empire. According to Johannes Käbin, the First Secretary of the ECP, these were the years to prepare the revolution in Estonia. ${ }^{39}$ Käbin's work was not a school history book, but a common interpretation of Estonian history from a communist point of view. Compared with the text written by Uustalu the development towards a Communist era seems to be very logical, but like the Russian October Revolution the result was totally uncertain and ended at that time otherwise in Estonia than in Russia. Käbin tells about the peace agreement of Brest-Litovsk between Russia and Germany, but does not say a word about the Estonian declaration of independence on 24 February 1918.

With the support of a British naval detachment the Finnish volunteers succeeded in intervening in Tallinn and helping Estonian national forces. According to Käbin the Estonian White troops forced workers into their ranks using the threat of death penalty. Anyhow Käbin confesses that the Estonian people supported the idea of a bourgeois republic and fought for it on the front. The fight on the Estonian soil ended in May 1919 when the Red Guard was defeated. Still Käbin writes about the Estonian independence war as a myth, because the blood of proletariat flew like a river when they did not want to fight in order to fulfil the interests of bourgeoisie. The winners showed that they did not give mercy to the defeated more than the suppressors of the revolution in Finland, Germany etc. When describing the support of Britain, the USA and France to Yudenich and the Russian White Guard Käbin even calls the new Finnish volunteers "Butchers". After unsuccessful battles of the Whites to conquer St. Petersburg, the peace treaty between Estonia and Soviet Russia was signed in Tartu in February $1920 .{ }^{40}$ Compared with a textbook used in Finnish schools in the 1960s and 1970s a great difference can be seen. In 1969 the authors Sarva and Niemi told about the birth of the Soviet Union under the headline "The international communist dictatorship". According to this book the position of lower classes under persecution, corrupted officials and the incompetence of the government woke a great dissatisfaction in Russia. Combined with heavy losses in the war the events led first to the February revolution. The independence of Estonia, Latvia and Lithuania is clearly brought to the reader. ${ }^{41}$

The "vsesoyuznyj" (all-Union) instructions put the highlight in the Baltic States to "bourgeois dictatorship". The focus of the work should have been in the re-building of the Soviet power and its revolutionary influence into the political, socio-economic and cultural life of Estonia, Latvia and Lithuania. ${ }^{42}$ When writing

39 Käbin, J. Oktyabr'skaya revolyutsiya i Estonskij narod. Tallinn, Eesti Raamat, 1967, 11.

40 Käbin, J. Oktyabr'skaya revolyutsiya, 47-56.

41 Sarva, G. \& Niemi, K. V. Historian oppikirja lukioluokkia varten. II osa, uusi ja uusin aika. Porvoo, WSOY, 1969, 155.

42 Samsonov, A. (ed.). NSV Liidu ajalugu, lühiülevaade, II osa, Suurest Sotsialistlikust Oktoobrirevolutsioonist tänapäevani. Translated by J. Janson \& T. Tender. Tallinn, Eesti Raamat, 1983, 320 . 
of independent Estonia Käbin calls it "a period under the yoke of "independence", a name given by the Estonian communist leader Kingissepp. According to him, Estonia depended politically and economically on capitalist powers, which made the country a half-colony. Furthermore, the imperialist countries fed Estonian bourgeoisie in order to keep the country as a platform for invasion into the Soviet Union in a new war. ${ }^{43}$ This really sounds familiar for a Finnish reader because of the negotiations in the Kremlin before the Winter War in 1939. Stalin and Molotov insisted on occupying naval bases in Finland and told the Finnish delegation: "A great power doesn't ask you for permission when it wants to attack through the Finnish territory into the Soviet Union." Käbin calls the regime of Konstantin Päts since 1934 a fascist dictatorship with only a short mention of the name of the President, which was banned in the Estonian SSR.

No wonder that the integration of Estonia under the government of Johannes Vares into the Soviet Union is described as a victory of the working class in summer 1940. The event is called a Socialist Revolution carrying the heritage of the Great October on the Estonian territory. ${ }^{44}$ There is no mention about the heavy pressure of the Soviet Union and the Red Army. Estonia's "voluntary" joining the Soviet Union continued even in President Putin's statement at the 60th anniversary of Victory Day on 9 May $2005 .^{45}$ For example Finnish students could read about this event already in the 1960s. Sarva and Niemi stated that out of the fear towards Germany the Soviet Union consolidated its position in the Baltic by forming military bases in these countries and at last Estonia, Latvia and Lithuania were annexed to the Soviet Union as Socialist republics. ${ }^{46}$ Every Finn understood that it did not happen voluntarily.

It is interesting that in the 1970s the German occupation of Estonia in 19411944 is not mentioned in every methodology book like for example the one by Liim $^{47}$, while some others like Eesmaa ${ }^{48}$ put a highlight on it. Kahk and Siilivask write about the character of a civil war between Estonians in the first months of the war. They also tell about Erna, a commando group trained in Helsinki and transported with motor boats to Estonia in July 1941. The authors claim that people soon destructed the group. ${ }^{49}$

According to Pavel Leibengrub Hitler said that German barons made a mistake by not diminishing the population of Estonia and Latvia. Hitler planned to settle them in the eastern side of Lake Peipsi, around Novgorod and in Karelia. ${ }^{50}$ Nobody

Käbin, J. Oktyabr'skaya revolyutsiya, 57.

Ibid., 69-76.

45 Helsingin Sanomat, 10.05.2005.

46 Sarva, G. \& Niemi, K. V. Historian oppikirja, 163.

47 Liim, A. Eesti töölisklassi revolutsioonilise liikumise ajaloo tundmaõppimisest keskkooli VIIIXI klassis. Tallinn, Eesti NSV Haridusministeerium, 1973.

48 Eesmaa, L. (ed.). Metoodiline abimaterjal ajaloo õpetamiseks V-XI klassis. Repetitio est mater studiorum - Kordamine on õpingute ema. Tallinn, Eesti NSV Haridusministeerium, 1974.

49 Kahk, J. \& Siilivask, K. Eestin SNT:n historia, 118.

50 Leibengrub in Õispuu, S. (ed.). Ideeline kasvatustöö, 15. 
told in Soviet times that Stalin fulfilled this plan by deporting a great deal of both peoples into Siberia. The headmaster of the Tartu 10th Secondary School Tarmo Kerstna describes the events of war in a very systematic way in a table of seven columns. There are all the roles of the peoples of the Soviet Union in the Great Patriotic War - except the Molotov-Ribbentrop pact from 1939, the co-operation of Nazi Germany and the Soviet Union in 1939-1941, the occupation of the Baltic States in 1940 and the Finnish Winter War of 1939-1940. ${ }^{51}$ When the Red Army reached Tallinn on 22 September 1944 and hoisted the red flag on Pikk Hermann tower, Käbin said the Estonian working people had returned themselves their own capital. Estonians would forever be grateful to all sons and daughters of the Soviet peoples who liberated their country and helped them to freedom and happiness again. ${ }^{52}$ In the same way Leonid Bogolyubov claims that the Estonians supported the Soviet Union all the way in the Great Patriotic War. ${ }^{53}$ The reader can only admire the logical style of the historians, which includes no doubts about the Soviet-style "liberation", "freedom" and "happiness".

After the war the ruling ECP realised a land reform and industrialisation. According to Käbin the bourgeois governments did not pay any attention to the oil shale industry. However, before 1965 the production of this fuel per capita in Estonia rose higher than the respective production in the USA, Great Britain and Western Germany. In industry Estonia succeeded in machinery, optical and electrical equipments, chemicals, textiles, shipbuilding, fishery etc. Yet - typical again - the numbers of growth are only presented in per cents, not in absolute figures. In comparison to Finland the growth in industrial production in Estonia in 1960-1964 was 10.3 per cent, while in Finland only 8.4 per cent. And from 1940 to 1966 the growth in Estonia was 1994 per cent, while in Finland 572 per cent. ${ }^{54} \mathrm{~A}$ big question is whether anybody took these numbers seriously without any information of the absolute figures of production. This very same method is used for example by Furaev still in 1985 in his Novejshaya istoriya. ${ }^{55}$ Anyhow, this is the place for the reader to see the pride of Estonians of their nationality and faster development than in Russia or some other parts of the Soviet Union. There are pictures in the book of new buildings, factories, shops, schools, institutes and even of song festivals, which then formed the origin of the Singing Revolution at the end of the 1980s.

The number of weekly lessons of history in the eight-year school was since 1959 as follows: 4 th grade $-2,5$ th grade $-2,6$ th grade $-2,7$ th grade -2 and 8 th grade -3 . In the 11-year secondary school the curriculum was the same as in whole

51 Kerstna in Õispuu, S. (ed.). Eesti NSV ajaloo käsitlemisest NSV Liidu ajaloo üldkursuses. Tallinn, Eesti NSV Haridusministeerium, 1978, 43-49.

52 Käbin, J. Oktyabr'skaya revolyutsiya, 87-88.

53 Bogolyubov in Õispuu, S. (ed.). Ajaloo ja ühiskonnaõpetuse kursuste põhiküsimusi. Metoodiline abimaterjal õpetajale. Tallinn, Eesti NSV Haridusministeerium, 1984, 29.

54 Ibid., 92-102.

55 Furaev, V. K. et al. Novejshaya istoriya (1939-1984). Moskva, Prosveshchenie, 1985, passim. 
Soviet Union. ${ }^{56}$ The Estonian intelligentsia succeeded in reanimating the national culture, which stayed very vital until the late 1970s. The schools developed rapidly too, and in 1956-1957 a total of 77 per cent of the Estonian schools taught in the Estonian language. ${ }^{57}$ Like in the whole Soviet Union 55 per cent of the history teachers were members of the CPSU in $1965 .^{58}$

\section{THE COLD WAR}

While in most of the books the picture of Estonia is seen from inside, the relations to capitalist countries are strictly formulated in the Kremlin. Already in 1951 the Soviet concept described American imperialists aiming from a cold war to World War III by threatening the humankind with the atom bomb, hydrogen bomb, bacteriological and chemical weapons and other mass destruction weapons. We should remember that when telling about history from the very beginning the same author only mentioned Lake Peipus in 1240, Livonia and Tallinn in the 16th century but never the name of Estonia. ${ }^{59}$

The era of Breshnev, which started in 1964 after Krushchev was deposed, returned the formal communism clearly even to school books. For example, the book Uusim aeg 1939-69 was printed in Tallinn, but it was translated from the Russian and all the authors are Russians. The picture given about the USA is very merciless: USA lost only a 70th part of human lives in WW II in comparison with the number of Soviet victims. However, American monopolies profited enormously from the war. The American imperialism resists revolutions in the whole world, supports reactionary governments acting against people, involves into domestic politics of several countries and acts as a gendarme of the world. ${ }^{60}$

According to Furaev, the most significant organisation of the aggressive foreign policy of the USA is the NATO. It is headed against socialist countries, movements of workers and democrats and liberation of people. The author swore that people of Vietnam would get help from the Soviet Union and other socialist countries in enlarging war against the USA. He promised that people of the USA would feel the consequences of this shameful adventure. ${ }^{61}$ The then European dictatorships Spain, Portugal and Greece show according to Furaev the crisis of the bourgeois ideology. ${ }^{62}$

56 Aaspere, L. Eestin sosialistisen neuvostotasavallan kansanopetusjärjestelmä. Tallinna, Eestin valtion kustannusliike, 1964, 55.

Grönholm, P. Kansallisen epäonnistumisen historia, 172-173.

Pesti NSV ajaloo küsimusi, 25

Pankratova, A. M. (ed.). Neuvostoliiton historia, keskikoulun X luokan oppikirja. Petroskoi, Karjalais-suomalaisen SNT:n valtion kustannusliike, 1951, 422; Pankratova, A. M. (ed.). NSV Liidu ajalugu, I osa. Tallinn, Pedagoogiline Kirjandus, 1948, passim.

60 Furaev, V. K. et al. Uusim aeg 1939-69. Tallinn, Valgus, 1970, 122-123.

61 Ibid., 126-127.

62 Ibid., 173. 
Furaev is very certain that the socialist countries dictate the direction of the development of the world. Yet the Socialist International, led by Social Democrats from Britain, France and Sweden has not built up any socialism. Factories in these countries still belong to capitalists who exploit workers. That is why the real socialism can be built only on Marxist-Leninist basis. ${ }^{63}$ In 1956 in Hungary the Soviet Union helped the people to defeat the counterrevolutionaries. The same way all the socialist countries gave brotherly help to Czechoslovakia in August 1968. Furaev also considers the Chinese Communist Party as a great harm to the international communist movement. ${ }^{64}$

Falsification of history has always been a weapon of dictatorships. When telling about Baltic history Küng describes the way it is done in Estonia. For example, the annexation of the Baltic area to the Russian empire in 1721 made a crucial change in the development of the area. According to books, in the Soviet Estonian schools the Russian democratic culture influenced the Estonian national culture and raised the cultural level of the people. And this happened in spite of the dark pressure of the Czar? The time of independence 1918-1940 is called bourgeois dictatorship and the real sovereignty started first in 1940. According to Küng this is a clear example of New Speak (by George Orwell), and discussion with Soviet communists is like hitting one's head on the wall. ${ }^{65}$

According to Küng the view of history is not consolidated but it can be changed depending on political circumstances. Stalin denied the original Marxist historiography in the 1930s and ever since studies had to be done from the proRussian point of view. The national history teaching stopped in Estonia during the occupation in 1940 and restarted first at the end of the 1950s. Even the ECP leaders confessed in private to Küng that school history books contained many falsifications: the harshest example is description of the events in 1939-1940. At the same moment they stated that it was a commonly accepted double morality that should not to be cared about. Everybody could make a difference between the truth and a lie. ${ }^{66}$

The literacy of the New Speak was needed to read instructions for teachers. When telling about the end of the bourgeois era Palamets writes that Estonian history had been changed to a barrier in order to avoid the real historical civilisation. In primary school the aim of teaching history should be to educate national spirit and love to fatherland and deepen the stately thinking among youngsters. These themes with high morale were repeated in the 5th and 6th forms. Palamets calls this repetition boring and claims that it restricted the liberal education of pupils. He also says that during the German occupation only German history was highlighted in Estonian schools and Estonian history had to be served as "a history

63 Furaev, V. K. et al. Novejshaya istoriya, 242.

64 Ibid., 249, passim.

65 Küng, A. Vad händer i Baltikum? Lund, Berglingska boktryckeriet, 1973, 70-71.

66 Ibid., 71-72. 
of Estonians' and Germans' common Fatherland". ${ }^{67}$ Even a foreigner can read here the criticism towards the Soviet power.

For the time being we can see some confessions in texts written in Russian and translated into Estonian. In the 1980s the Finnish Winter War 1939-1940 was first mentioned in NSV Liidu ajalugu II. The Hitler-Stalin pact from 23 August 1939 was already public earlier, but not its secret protocol including the division of Europe. The change of power in Estonia in 1940 is called "the overthrow of the Fascist dictatorship and establishment of the people's government". ${ }^{68}$ Of course the same book tells about "the complete and definite victory of socialism". There is no other mention about Baltic States but the famous song festivals. ${ }^{69}$ The volume was printed only five years before the Singing Revolution and eight years before the Big Crash.

\section{CULTURE IN THE ESTONIAN SSR}

Käbin confirms the number of literate Estonians given by Uustalu. But he claims that only half of the pupils completed the three year elementary school. Now, in the 1960s, most of the youngsters of the Estonian SSR completed the 11 grade secondary school. Käbin writes that in bourgeois Estonia the number of children of capitalists and officials among university students was 10 times higher than of workers and small clerks and 15 times higher than of children of working peasants. During the bourgeois era 1919-1939 a total of 5689 persons got a diploma from a college or university, while in the Soviet era 1945-1965 the respective number was $28500^{70}$, and according to Kahk and Siilivask in 1950-1970, $38900 .^{71}$ However, none of the authors mentions that the enlargement of higher education also happened in the West after the war at least in the same measure. According to Küng there were about 25000 students in Estonian colleges and universities at the beginning of the $1970 \mathrm{~s}^{72}$

Grönholm also has found this kind of presentation in 1971 by Elango, who praised only the October Revolution and the Bolshevik school reform in Russia for all the progressive characters of Estonian school, like compulsory education, learning in the mother tongue, free education and non-religious education. The blame of giving up attending school because of illness or lack of money was put only on bourgeois policy of education in 1920-1940. According to Grönholm even in 1980, an Estonian Liim described the efforts of bourgeoisie to limit the higher education only for their own children. ${ }^{73}$

${ }^{67}$ Palamets, H. Ülevaade ajaloo õpetamise arengust. Tartu, Tartu Riiklik Ülikool, 1968, 117, 138.

70 Käbin, J. Oktyabr'skaya revolyutsiya, 119-121.

71 Kahk, J. \& Siilivask, K. Eestin SNT:n historia, 151

72 Küng, A. Vad händer i Baltikum?, 65.

73 Grönholm, P. Kansallisen epäonnistumisen historia, 391-392 (orig. Elango, Õ. Haridus ja teadus, 1971); Liim, A. Kultuuri arengu üldjooni. Kool ja haridus. Kõrgharidus ja teadus. Eesti koolid ja teadusasutused Nõukogude Liidus. - In: Eesti NSV ajalugu. Kõrgkoolide õpik. II osa. Comp. K. Siilivask. Tallinn, Valgus, 1980. 
Küng compared Soviet and Swedish schools in an interesting way in 1973. He pointed out the following features: ${ }^{74}$

1. The Swedish school teaches a pupil to independent, critical thinking, but the Soviet school does not.

2. Democratisation of working methods has not begun in Soviet schools, if there has been any thinking about it. The Soviet school presents clearly the whole society by stressing respect towards authorities and leaders. Children wear uniforms and have to stay in military attention when answering to teachers. Physical punishment is allowed but seldom needed. According to Estonian sources this was either a misunderstanding or propaganda: Physical punishment was totally ruled out in the educational literature of the Soviet Union. The Educational Code of the ESSR also prohibited inhumane action but did not mention physical punishment directly.

3. Co-operation is not encouraged either among pupils or between the teacher and the pupil. Instead all concentrate on competition in order to get better results. The schools organise annual competitions to find the best student in the republic in languages or sciences. Universities pick up the best students from secondary schools. Notice boards in schools are often in use to appreciate especially hard-working students or to blame "bad" pupils, e.g. those who go to church. (In my opinion the level of learning foreign languages was held low in the Soviet Union on purpose to avoid Western information.)

4. Soviet teachers still give homework in order to keep the level of knowledge high. (I think the Swedish teachers and researchers have returned to giving homework after a while of "free education".)

5. Knowing facts is more valuable in the Soviet Union. Theoretical subjects get more attention than practical, except the aesthetic education in which the Baltic schools have gone further than others in the Soviet Union.

6. The domestic language is voluntary in Russian schools in the Baltic States and learning begins in the $3 \mathrm{rd}$ form with two lessons a week. Theoretically the Russian language is voluntary in Estonian schools, and learning starts from the 2nd form with four lessons a week.

7. Teaching of Marxism-Leninism begins in the 8th form and goes on in the secondary school and in the university with 6-7 lessons a week. For example a medical student cannot graduate without passing an exam in MarxismLeninism and the history of the CPSU. All the talented youngsters are supposed to be members of the Komsomol (Young Communist League) and study the "holy writings" of Marx and Engels. A student who stays outside will get a bad reputation and risk his future career.

8. Soviet students get military education already in the 9th form. They learn to handle a machine gun and practise sharp shooting. Many male students of universities get trained to reserve officers during their studies.

9. Boarding schools are encouraged in the Soviet Union. This makes it more difficult for parents to tie their children to bourgeois and religious values.

74 Küng, A. Vad händer i Baltikum?, 67-69. 
10. There are special schools in sciences, languages, sports and music. For example in language schools the number of lessons in foreign languages is three times greater than in common schools and the student groups consist of no more than 12 persons. Pupils from these elite schools can choose themselves a further alternative of studies in universities. This also causes a problem because the children of intelligentsia are overrepresented. However, the officials think that this system can produce highly educated and extremely valuable specialists for the state.

A history teacher of Jõgeva secondary school, Eino Veskis, writes about education of the proletarian internationalism through e.g. interviewing grandparents. This internationalism is also presented in his school by having friendship schools in Archangel, Cesis, Riga, Minsk, Kishinyov, Vilnius and Kiev. ${ }^{75}$ No wonder, there was no school from Helsinki, Stockholm, Vienna or Bern, just to mention some cities from neutral countries. According to Õispuu the Estonians have unbreakable connections to Soviet patriotism, the friendship of peoples of the Soviet Union and proletarian internationalism. As late as at the end of the 1970s there was a whole chapter in the book about the class struggle in Estonia. ${ }^{76}$

From a mere pedagogical point of view history has an informative task and especially history teachers tried to keep it up in schools and universities. Only a neutral introduction to information about the Republic of Estonia in 1918-1940 made many official explanations questionable. Besides there were signs in Soviet society of loosing faith in the utopia, omnipotence and infallibility of the Party at least in the 1970s. Many citizens tried to improve their own wealth by stealing from the state and companies. At the same time the Nomenclatura alienated icreasingly from common Soviet people. ${ }^{77}$

The ideological education was disliked by many Baltic people according to Küng. Very few accepted the use of the school as a first aid in the ideological pressure with communist and pro-Russian examples. They said that the Soviet school had become a church of the Modern Communist Religion. School creates attitudes in every society. The question was not whether it is good or bad, but whether we think that "right" or "wrong" values get support. ${ }^{78}$ Beside "Scientific Atheism", especially for teaching World War II the instructions were very detailed. In a methodology book printed in Moscow for the whole Soviet Union the town of Oryol was taken as an example for the 11th form. Students should observe (1) the youth of the town on the front and in the back lines, (2) the activity of inhabitants in post-war rebuilding, (3) the participitation of youngsters in agricultural work and of members of the Komsomol in building up the country, (4) the movement of communist storm troopers among the workers of the town and (5) the activity

75 Veskis in Õispuu, S. (ed.). Ideeline kasvatustöö ajaloo õpetamisel, 57.

76 Õispuu, S. (ed.). Kommunisticheskoe vospitanie uchashchikhsya na urokakh istorii. Tallinn, Eesti NSV Haridusministeerium, 1978, 11, 87-101.

77 Grönholm, P. Kansallisen epäonnistumisen historia, 441, 456.

78 Küng, A. Vad händer i Baltikum?, 67. 
of inhabitants in fulfilling the decisions of the 22nd Congress of the CPSU. ${ }^{79}$ I only can imagine the level of enthusiasm with which the Estonian students read these lines and edited wall newspapers.

According to Käbin, the Estonian literature became famous in the whole Soviet Union and even wider thanks to translation into Russian. There were 199 translated Estonian books with 600000 volumes published in other languages during the two decades of bourgeois Estonia, while the respective numbers under the Soviet power are 435 with 11 million volumes. And vice versa: the Estonians now (1967) have a possibility of reading the best Soviet literature in their mother tongue. The aim of this was to bring all the Soviet peoples closer to each other and to liberate the Estonian literature from its national isolation and limited bourgeois era. The number of theatres, concert halls and cinemas grows every year. There are several famous actors, poets, authors, painters, musicians etc. in Estonia. Käbin says that the Estonian culture is formally national but its contents are socialist. ${ }^{80}$ This repeating concept of the united culture of the peoples of the Soviet Union makes the reader doubt that national characters still remain as the target was to create a Homo sovieticus.

Interesting enough, the only allowed style of arts was socialist realism. Western surrealistic painters are called absurd. After WW II abstract art became popular in capitalist countries. According to Furaev this abstractionism has nothing in common with the real art. The same way he judges the pop-art, which presents animals made of pots, pieces of advertisement posters and concentrate stuffs. The same effects are used in music, films and theatre. The author claims that the big bourgeoisie wants to make the idea of real art worse among people and destroy the civilising power of the art. ${ }^{81} \mathrm{We}$ can physically feel the opinion of the grey haired custodian of the Culture Department of the CPSU, which firmly consolidated in the days of Stalinist purges after a short era of the avant-garde.

Käbin cites the programme of the CPSU, which guarantees to every citizen the freedom to educate their children in their mother tongue. However, officials also recommend parents that their children should study the Russian language. Without knowing Russian it is difficult to learn to know the great richness of the Soviet culture. Knowing the Russian language plays a great role in formulating highly educated national cadres, furthermore the whole Estonian national Soviet culture. ${ }^{82}$ It was very difficult or even impossible to write diploma works or dissertations in Estonian. As a small detail: it often felt ridiculous for a Finn to read Estonian names transliterated through Russian into English, for example Vaino Vyalyas (Vaino Väljas).

Väljas was very popular among Estonian citizens. Because of the increasing power of the gerontocracy in the Soviet Union he was named Ambassador in

\footnotetext{
79 Akademiya Pedagogicheskikh Nauk RSFSR. Za povyshenie effektivnosti urokov istorii i obshchestvovedeniya v srednej shkole. Moskva, Prosveshchenie, 1964, 192.

Käbin, J. Oktyabr'skaya revolyutsiya, 123-125.

Furaev, V. K. et al. Uusim aeg 1939-69, 170.

Furaev, V. K. et al. Novejshaya istoriya (1939-1984), 126.
} 
Venezuela in 1980. After that there were only two native Estonians at the top of the party hierarchy: Arnold Rüütel and Rein Ristlaan. The latter undertook the task of Russification in educational and cultural policy. As is well known the First Secretary of the ECP was Karl Vaino (Kirill Voinov), who could not speak fluently Estonian after 30 years of living in Estonia. ${ }^{83}$

Estonia still witnessed a late effort of Sovietisation in language policy and education in 1978. The USSR Council of Ministers made a secret decision to increase using the Russian language in administration and education. Even kindergartens should have been half-day Russian and an intensive learning of Russian should have started already in the 1 st form. ${ }^{84}$ Teaching in Estonian should have stopped in the 8 th form. ${ }^{85}$

\section{THE LIFE OF A COMMON MAN}

In many ways Käbin advertises the end of unemployment in the circumstances of socialism. Like the numbers of production he tells about the wages rising 20 30 per cent in the 1960s ${ }^{86}$ Economists have pointed out that the Soviet Union printed more money bills, kept the prices low, but there was a constant deficiency in the shops. The former Prime Minister of Estonia, Edgar Savisaar told in 2005 in Helsinki that the building of the Viru Hotel in the centre of Tallinn in the 1970s taught Estonians new methods of work and also working morale. ${ }^{87}$ In the renovation of the Viru in the 1990s the constructors tore up a huge cold-storage room. The reason why it had been made so large was simple: they had to buy meat as much as possible every time it was for sale. ${ }^{88}$

The agricultural production of Estonia had a high quality and would have been sufficient for the republic itself. Käbin again shows the pride in Estonians of this national achievement. ${ }^{89}$ However, most of the output was exported to other parts of the Soviet Union. Yet the people were told quite the contrary. In a demonstration in Moscow in 1989 a teacher claimed: "Nam eshcho nado kormit' Pribaltiku!" (We even have to feed the Baltic republics). ${ }^{90}$

According to Käbin, it was only thanks to socialism that apartment houses and schools, water pipes and sewer systems were built in Estonia. The houses of the farmers are getting empty as the inhabitants move to modern house complexes of sovkhozes and kolkhozes. As a result of the ideals and political education of the Communist Party a new human being is formulating. Käbin introduces here Alfred

83 Grönholm, P. Kansallisen epäonnistumisen historia, 279-280.

84 Ibid., 283.

85 Graf, M. \& Roiko-Jokela, H. Vaarallinen Suomi. Jyväskylä, Kopijyvä Oy, 2004, 108.

86 Käbin, J. Oktyabr'skaya revolyutsiya, 127-129.

87 Helsingin Sanomat, 20.01.2005.

88 Helsingin Sanomat, 15.06.1995.

89 Käbin, J. Oktyabr'skaya revolyutsiya, 130.

90 Helsingin Sanomat, 10.05.1989. 
Valdov, a worker from a machine factory and a hero of Socialist labour as a favourite of all the Estonians. ${ }^{91}$

A republic could not have any privileges in the Soviet Union. The CPSU carried the responsibility of the development in every republic. Käbin again reminds the reader that Estonia joined the Soviet Union and a new economic system voluntarily. Together with other republics of the Soviet Union Estonia helps all the socialist countries in strengthening the global system of socialism. Ideologically, the imperialistic propaganda tries to harm the brotherhood and friendship of the peoples of the Soviet Union. An Estonian is always at home whether he comes to Khisinev, Yerevan, Irkutsk or Moscow, always with his or her own people, among friends and fellow citizens. And those moving to Estonia from other parts of the Soviet Union feel themselves comfortable and take part in the building up of the republic. ${ }^{92}$ The last sentence has proved true because persons of other nationalities living in Estonia did not leave the country after the collapse of the Soviet Union and re-declaration of Estonian independence in 1991.

\section{ESTONIA SEEN FROM OTHER COUNTRIES}

Among those visiting Estonia there are some who emigrated already in the era of the Czar, those who left during the bourgeois dictatorship mostly due to unemployment, like Käbin puts it. The last wave floated out during the German fascist occupation, some escaping the terror of Hitler, some as victims of fascist anti-Soviet propaganda. Käbin calls the information of committees of Estonians living in exile "dirty lies about the Estonian SSR". Yet from year to year the number of visitors to the country of fathers and uncles grows and they are happy to see the development in socialist Estonia. He then cites Estonians living in the USA, Canada and Australia praising for example the sanatoria of Estonia. ${ }^{93}$

In May 1967 a week of Estonian culture was arranged in Finland. The performers were from the Estonia Theatre, the Academic Male Choir, the ensemble Laine, authors, painters and other cultural workers. The Finnish press, expressing the opinion of thousands of the audience, gave the greatest appreciation to the Estonia Theatre. ${ }^{94}$ However, Käbin does not tell about the visit of the Finnish president Kekkonen to Tartu in 1964, where he surprised all the hosting politicians, not the least Russians, by speaking Estonian and highlighting the connections between Estonia and Finland. Kekkonen directed his words to Estonian students by saying that they would have the responsibility of the spiritual, economic and technological development of Estonia. They should turn their country into a developed and progressive land where the beautiful Estonian style of life would

91 Käbin, J. Oktyabr'skaya revolyutsiya, 130-133.

92 Ibid., 136-142.

93 Ibid., 151-153.

94 Ibid., 156. 
always continue. Unfortunately, this visit of Kekkonen was seen in the West mostly as only a move of the Kremlin, which was totally against its purpose. ${ }^{95}$

After this visit, in 1965, a regular passenger ship line was opened between Tallinn and Helsinki with Georg Ots. ${ }^{96}$ At the same time the quiz "Naapurivisa" was broadcast both on Estonian and Finnish television, and the watchers became familiar with Hardi Tiidus and Esko Kivikoski. Later on the meat expert Väinö Purje from the Finnish K-market was the most popular Finn in Estonia. In the 1990s a study was made in the University of Massachusetts about how the Western media, mostly from Finland, little by little influenced and at last broke the Soviet propaganda in Estonia. ${ }^{97}$

\section{GRANDE FINALE}

Great discoveries are often simple. Hilja Rauk has collected definitions of pupils in a remedial school about history. According to her, history is a very difficult subject to teach in a remedial school because it presupposes conceptual thinking. The pupils for example wrote that (1) history tells about old times; (2) history tells about great wars and accidents; (3) in history we learn about burning mansions and (4) history never ends. There also is a table, well known in the USSR, about the number of socialist countries before World War II (1) and after that (12). ${ }^{98}$ However, it still remains a secret how socialism was set up: with guns and occupations.

Õispuu states that in the future people in Europe and America should live and work according to the Final Act of OSCE signed in Helsinki $1975 .{ }^{99}$ This is remarkable because people in Baltic countries did not like the act of freezing their position in the Soviet Union. Still, the requirements of freedom of speech and human rights meant ruining the Soviet Union. According to Õispuu, the man of the future knows much about history, protects his world view, resists chauvinism, racism, uncertainness, religion and other prohibited subjects. He appreciates the achievements of the whole mankind, his own profession and party, his family and himself. It is forbidden to rip out uncomfortable pages from the history. ${ }^{100}$ (!) Every historian could tell how much the Soviet Union de facto wiped out and some-

95 Graf, M. \& Roiko-Jokela, H. Vaarallinen Suomi, 80 (ironically enough, Kekkonen found support from Toini Käbin, a Finn from Ingermanland married to Johannes Käbin).

96 Kahk, J. \& Siilivask, K. Eestin SNT:n historia, 154.

97 I sent a note about Juha Vainio's song "Aleks ja Jaan" to the professor. Aleks and Jaan were brothers who rowed over the Gulf of Finland during the Soviet era in order to look for a better life. Unfortunately, they only found a closed food shop in Porkkala. They then decided to row back to Estonia singing "The Finnish and Russian lunch bags are alike". Publishing this humour presented the Finnish guts in the 1980s.

98 Rauk, H. Ajaloo käsitlemisest abikoolis. Tallinn, Eesti NSV Haridusministeerium, 1980, 9, 29.

99 Õispuu, S. Ajaloo ja ühiskonnaõpetuse kursuste põhiküsimusi, 54.

100 Ibid., 55. 
times rehabilitated people and events. Õispuu still edited probably the last history methodology book in the Soviet era. ${ }^{101}$ But the text was anachronistic already when it was written.

According to Grönholm the Soviet strategy in history writing seems to have been as follows: When the Soviet narrative consolidates and stays as the only official interpretation, it will little by little replace the tradition of the national historiography. The focus indeed was in school teaching and ideological education of the youth that aimed at shaking the national identity. Then the younger generation with no experience of independence would be confused and mistrust the older one. Then the open propaganda would have been replaced with indoctrination. ${ }^{102}$

In 1980 there were demonstrations in Tallinn by Estonian students against the Soviet rule. Actually the change went on with perestroika and glasnost in 1985. Sirkka Ahonen has told about the great change of curricula between 1988 and 1990. Names like Õispuu, Palamets, Piirimäe and Vahtre appear among the writers from the time of the Estonian SSR. ${ }^{103}$ However, they now could write freely of the Estonian national history and fill the gaps in it.

\section{ANSWERS}

1. After the war until the death of Stalin in 1953 all the material in history teaching was translated from Russian. There was not the name "Estonia" and mentions about other "good" rulers like the Swedes were wiped out. Even in the exhibition of Estonian history (put together in Soviet time) in the Bishop's Castle of Kuressaare the era between ca. 1400 and 1721 is missing. The first history of the Estonian SSR came out in 1952. Estonians living in the West published many reliable books about Estonian history and some succeeded in smuggling them into Soviet Estonia. Some national figures were to be seen in history books from the thaw of Khrushchev on. One explanation can be the agricultural and industrial heritage and the Lutheran religion and working morale. They brought wealth to the republic, which could be proudly presented in the circumstances of socialism in history books too. Generally one can say that the farther away in the past the subject was the wider was the freedom of an author. However, from the end of the 19th century on the censorship was very heavy.

2. Of course the number of nationalist characteristics increased. Only the MarxistLeninist and Great-Russian control was so powerful that authors could not write freely. Some signs can be seen of loosing the faith in the socialist utopia and the Legend of October. They criticised harshly e.g. German knights and

101 Õispuu, S. (ed.). Vspomogatel'nyj material uchitelyu dlya obucheniya istorii Éstonskoj SSR. Gosudarstvennyj komitet po narodnomu obrazovaniyu Éstonskoj SSR, 1990, passim.

102 Grönholm, P. Kansallisen epäonnistumisen historia, 486.

103 Ahonen, S. Clio sans uniform, 100-128. 
occupiers in history books, but Estonians could read the texts as double entendre: the criticism was directed to Soviet power.

3. According to Küng the best that happened in culture in Estonia during the Soviet era was the possibility for most of the people getting the education they wanted. There were some groups without this right like religious youngsters, political prisoners and "class enemies" and often their children. Some Estonian students were transferred to Russian faculties or working places, also for the first three years after graduating. However Küng asked a good question in 1973: The Soviet Union is more powerful than the Czarist Empire. Yet even Hitler's Third Reich did not last for a thousand years but only twelve. No Empire has stayed forever. Why should the Soviet Union be an exception? ${ }^{104}$ Eighteen years later Estonia was free and independent again.

104 Küng, A. Vad händer i Baltikum?, 67, 232.

\section{AJALOO ÕPETAMISE METOODIKA JA AJALOORAAMATUD EESTI NSV-S}

\section{Kari KAUNISMAA}

Nõukogude Liidus kui suletud ja tsentraliseeritud süsteemis kujunes koolis õpetatav ajalugu ametlikuks eneserepresentatsiooniks. Eesti NSV-s lisandus taotlus kustutada eestlaste teadvusest Eesti iseseisvuse ajajärk (1918-1940). Nõukogude perioodi algul töötasid veel Eesti Vabariigis hariduse saanud õpetajad ja kasutati endist õppematerjali. Peagi aga hakati Eestisse tooma ajalooõpetajaid teistest NSV Liidu osadest, aastatel 1946-1948 korraldati õpetajate ümberõpet ja juurutati Nõukogude ajalooõpetus tegelikult.

Nõukogude ajalookäsitlusele oli iseloomulik väikeste rahvaste rolli ning nende püüdluste ignoreerimine ja vene rahva kui kaitsja ning vabastaja ülistamine.

Sõjaajast kuni Stalini surmani tõlgiti kogu ajaloo õpetamisel vajalik materjal vene keelest. Õpikutes ei esinenud isegi sõna Eesti. Nõukogude okupatsioon lõpetas kauaks ajaks oma maa ajaloo õpetamise, seda alustati taas 1950. aastate teisel poolel. Õpikuid ja muid õppematerjale avaldati tugeva parteilise ja suurveneliku kontrolli all, mis ei andnud autoritele võimalust vabalt kirjutada. Üks rahvale mõistetamatu põhikontseptsioon oli, et 1940. aastal Eesti ei kaotanud iseseisvust, vaid just vastupidi: saavutas selle NSV Liidu koosseisus. Rahvuslikku ajaloonägemust anti edasi perekonnaringis suulise traditsioonina. Eesti rahvusliku ajalookäsitluse traditsioone jätkasid emigrandid Läänes. 